The publisher gratefully acknowledges the generous support of the Ahmanson Foundation Humanities Endowment Fund of the University of California Press Foundation. The publisher also gratefully acknowledges the support of the Harvard Historical Series. 


\title{
Deep History
}

The Architecture of Past and Present

\author{
Andrew Shryock \\ and Daniel Lord Smail
}

WITH

Timothy Earle

Gillian Feeley-Harnik

Felipe Fernández-Armesto

Clive Gamble

April McMahon

John C. Mitani

Hendrik Poinar

Mary C. Stiner

Thomas R. Trautmann

따

UNIVERSITY OF CALIFORNIA PRESS

Berkeley · Los Angeles · London 
University of California Press, one of the most distinguished university presses in the United States, enriches lives around the world by advancing scholarship in the humanities, social sciences, and natural sciences. Its activities are supported by the UC Press Foundation and by philanthropic contributions from individuals and institutions. For more information, visit www.ucpress.edu.

University of California Press

Berkeley and Los Angeles, California

University of California Press, Ltd.

London, England

(C) 20 I I by The Regents of the University of California

Library of Congress Cataloging-in-Publication Data

Shryock, Andrew.

Deep history : the architecture of past and present /

Andrew Shryock and Daniel Lord Smail ; with Timothy

Earle ... [et. al.].

p. $\mathrm{cm}$.

Includes bibliographical references and index.

ISBN 978-0-520-27028-2 (cloth : alk. paper)

I. Human evolution. 2. Social evolution.

3. Anthropology, Prehistoric. 4. World history.

I. Smail, Daniel Lord. II. Earle, Timothy K. III. Title. GN28I.S457 2OII

$599.93^{1} 8$ - dc22

201 IOI 7773

Manufactured in the United States of America

$\begin{array}{llllllllll}20 & \text { I9 } & \text { I } 8 & \text { I7 } & \text { I6 } & \text { I5 } & \text { I4 } & \text { I3 } & \text { I2 } & \text { II } \\ \text { I0 } & 9 & 8 & 7 & 6 & 5 & 4 & 3 & 2 & \text { I }\end{array}$

In keeping with a commitment to support environmentally responsible and sustainable printing practices, UC Press has printed this book on Rolland Enviroıoo, a Io०\% postconsumer fiber paper that is FSC certified, deinked, processed chlorine-free, and manufactured with renewable biogas energy. It is acid-free and EcoLogo certified. 